\title{
Insecticidal Effect of Ethnobotanical Plant Extracts Against Anopheles Arabiensis (Diptera: Culicidae) Under Laboratory Condition
}

\section{Desta Ejeta Fereda ( $\square$ desta.ejeta@yahoo.com )}

Assosa University https://orcid.org/0000-0003-2171-1998

Ansha Asme

Assosa University

Animut Asefa

Assosa University

\section{Research}

Keywords: Anopheles arabiensis, botanical insecticide, Dangur, Ethnobotanicals, Malaria

Posted Date: September 28th, 2021

DOl: https://doi.org/10.21203/rs.3.rs-817855/v2

License: (a) (1) This work is licensed under a Creative Commons Attribution 4.0 International License. Read Full License 


\section{Abstract}

Background: The emergence and spread of resistant strains of malaria vectors to chemical insecticides are becoming major problem for malaria vector management. Natural plant products play a vital role to resolve the current challenge of malaria control.

Objective: The current study was conducted to evaluate insecticidal effect of ethnobotanical plant extracts against the primary malaria vector, Anopheles arabiensis in Northwestern Ethiopia.

Methods: Primarily, ethnobotanical plants used for Anopheles mosquito control was surveyed in Dangur district, Northwestern Ethiopia. Insecticide susceptible strains of Anopheles arabiensis mosquito were reared in insectary of tropical and infectious diseases research center, Assosa university. The larvicidal and adulticidal potentials of frequently used plant extracts against susceptible strains of laboratory colony were evaluated.

Result: A total of fifteen plants were identified as ethnobotanical plants helping the local people for mosquito control. Azadirachta indica, Ocimum lamiifolium, Ocimum americanum, Moringa olifiera leaf, and Moringa olifiera seed species of local plants were found to be frequently used to kill and/or repel mosquitoes in the study district. All the plant extracts were found to have potential larvicidal activity against $4^{\text {th }}$ instar larvae of $A n$. arabiensis and only ethanol and methanol extract of $A$. indica and $O$. lamiifolium were found to have potential adulticidal effect against adult of $A n$. arabiensis. The highest larvicidal activity was observed in ethanol extract of $A$. indica with $95 \%$ larval mortality and lowest LC50 of $40.73 \mathrm{ppm}$ and LC90 of $186.66 \mathrm{ppm}$. The highest adulticidal activity was observed in methanol extract of $A$. indica with $75 \%$ adult mortality at $300 \mathrm{ppm}$ and lowest LC50 of $106.65 \mathrm{ppm}$ and LC90 of $1293 \mathrm{ppm}$. The lowest larvicidal and adulticidal activity was observed in methanol extracts of $O$. lamiifolium with $63.35 \%$ larval mortality and leaf extract of $M$. olifiera with $50 \%$ adult mortality at $300 \mathrm{ppm}$, respectively.

Conclusion: ethanol extract of $A$. indica exerted a remarkable larvicidal effect against $A n$. arabiensis and thus it can be used for botanical mosquito insecticide development.

\section{Introduction}

Anopheles arabiensis is the principal malaria vector in Ethiopia having a wide distribution while An. pharoensis, An. funestus, An. nili, and An. stephensi have secondary role in malaria transmission in the country [1, 2, 3]. Vector control is a crucial prevention tool to mitigate the diseases. Long-lasting insecticidal nets (LLINs) and Indoor Residual Spray (IRS) are among the most effective malaria vector management strategies recommended in Africa. However, the wide spread of insecticide resistant strains of Anopheles mosquito is challenging the chemical insecticides-based malaria control strategies. Insecticide susceptibility tests carried out in Ethiopia have shown different levels of resistance by the principal vector to insecticides in use for IRS and/or to treat nets $[4,5]$. For these reasons, looking for alternative option is becoming major interest of scientists and policy makers working in the area.

Traditionally or culturally, different communities use different plants in various forms to protect themselves against mosquitoes and other insect bites [6,7]. Naturally occurring compounds and their derivatives are of increasing interest for the development of new insecticidal compounds against malaria vectors. Plants possess

Loading [MathJax]/jax/output/CommonHTML/jax.js at are selective, biodegradable, and have minor or no adverse 
effects on non-target organisms and the environment [8]. Reports indicated that the essential oils and extract of local plants have a promising larvicidal, adulticidal, and repellent activities against malaria vectors $[9,10]$. Gathering information about ethnobotanical plants used in particular society and evaluating their efficacy is important. Therefore, the main objective of the present study was to investigate the insecticidal effect of ethnobotanical plant extracts against $A n$. arabiensis under laboratory condition.

\section{Materials And Methods}

\section{Descriptions of the Study Area}

Ethnobotanical collection was conducted in in three purposively selected kebeles namely; Manbuk 01, Kitil, and Adipopo of Dangur district, Northwestern Ethiopia. Dandur district is situated $687 \mathrm{~km}$ away from the capital city of the country, Addis Ababa, in the Northwest Ethiopia (Fig. 1).

The district has an estimated total population of 68,653. Geographically, the district lies at latitude and longitude of $11^{\circ} 30^{\prime} \mathrm{N}$ and $35^{\circ} 50^{\prime} \mathrm{E}$, respectively with elevation ranging from $672-2731$ meter above sea level. Based on the information from metrological data in 2021, the area has mean annual rainfall ranging from 700 to $1400 \mathrm{~mm}$ per year and mean annual temperature ranging from $26-35^{\circ} \mathrm{C}$ per year.

\section{Ethnobotanical Data Collection Techniques}

Semi-structured interviews were prepared for inhabitants/key informants of the three kebeles (Manbuk 01, Kitil, and Adipopo) and it was used as a guide following Martin [11]. A total of 20 key informants were identified based on the recommendations of local authorities and knowledgeable elders who were suggested by respective kebele elders. Key informants were interviewed to identify plants they use to repel and/or kill insects in general and mosquitoes in particular.

\section{Voucher Specimen Collection and Identification}

Voucher specimens of the reported plants as repellant against mosquito vectors were collected and identified with taxonomic keys [12].

\section{Preparation of Crude Plant Extracts}

Plant extraction was conducted in the microbiology laboratory, Assosa University. The leaves and seeds of the plant were washed using clean water thoroughly and air-dried under shade at room temperature for 15 days. Then, the dried materials were ground separately to powder using a grinding mill. The powdered material was macerated with ethanol and methanol using Erlenmeyer flasks and placed on an orbital shaker at $60 \mathrm{rpm}$ at room temperature for 72 hours [13]. Then the plant extract was filtered through cotton and subsequently with Whatman filter paper $(12.5 \mathrm{~cm}$ size). Filtrates were concentrated using a rotary evaporator to remove solvents from the extract. The crude extracts were then collected in small volume beakers and kept in the freezer until used mosquito efficiency tests.

\section{Mosquito Rearing}

Larvae of Anopheles arabiensis were obtained from Tropical and Infectious Diseases Research Center insectary laboratorv. Assosa Universitv. Mosauitoes were reared using the standard procedures. They were maintained at Loading [MathJax]/jax/output/CommonHTML/jax.js 
$25 \pm 2^{\circ} \mathrm{C}$ temperature and $80 \pm 10 \%$ relative humidity and $12: 12$ light and dark photoperiod. larvae were fed with yeast a 3:1. When Pupae were formed no food was supplied and transferred to the cup that contains water by disposable pipettes and put in screened cages for adult emergence. The adults were fed on $10 \%$ glucose solution soaked in cotton pads, in addition to an animal (rabbit with shaved back and belly) blood meal given to the females twice per week. A petri dish lined with a moist cotton piece and covered with filter paper was put inside each cage for eggs lying [14]. By doing so, 4 th instar larvae and 2-5 day of adults were continuously available for different bioassay tests.

\section{Larvicidal Activity}

\section{Preparation of test and control solutions}

$200 \mathrm{mg}$ of the dried crude ethanol and methanol extract of each plant were placed in a standard measuring flask and distilled water to prepare $20 \mathrm{~mL}$ of $1 \%$ stock solution. $0.1 \mathrm{~mL}$ of Tween 80 was used as an emulsifier. From the $1 \%$ stock solution, concentrations of $50,100,150,200,250$, and $300 \mathrm{ppm}$ were prepared by adding the appropriate volume of dilution. $0.1 \mathrm{~mL}$ of Tween 80 was made up to $100 \mathrm{~mL}$ distilled water to serve as the negative control solution [14].

\section{Larvae bio-assay with crude leaf extract}

In the first phase of bio-assay, the mosquito activities of frequently used plants ethanol and methanol of crude extracts of the leaves and seed were screened at 300 ppm concentration. Batches of 204 th instar larvae of $A n$. arabiensis were transferred using a dropper to $200 \mathrm{~mL}$ glass beakers each containing $100 \mathrm{~mL}$ of water and one batch as a negative control for each concentration. Each test was run three times. The test containers were held at $25 \pm 2^{\circ} \mathrm{C}$ and $80 \pm 10 \%$ relative humidity with a photoperiod of 12 hours light followed by 12 hours dark. Larvae mortality was recorded after 24 hours of exposure in each concentration of test solutions [14].

\section{Determination of LC50 and LC90 of the crude leaf and seed extract of test plants}

Based on the preliminary screening, ethanol and methanol of the leaf and seed of plant extract were selected and subjected for dose-response bioassay at the concentrations of 50-300 ppm. The average mortality after 24 hours was recorded and used to determine LC50 and LC90 values [14].

\section{Adulticidal Activity}

\section{Adult bio-assay with crude leaf extract}

The triplicate series contained twenty females of An. arabiensis in each tube. In the first phase of bio-assay, the mosquito activities of ethanol and methanol crude plant extracts were screened at $300 \mathrm{ppm}$ concentration. This concentration was impregnated into filter papers $(12 \times 15 \mathrm{~cm})$. Only distilled water is used as a negative control. The impregnated papers were air-dried for 5 minutes and then inserted into an exposure tube in the WHO testing kit. Twenty 2-5 days of old blood-starved female mosquitoes were introduced into the holding tube and held for 1 hour to acclimatize. The mosquitoes were then transferred by gentle blowing in the exposure tube. After 1 hour in the exposure tube, mosquitoes were then transferred back to the holding tube to recover. A pad of cotton soaked with $10 \%$ glucose solution was placed on the mesh screen to feed recovering experimental and control Loading [MathJax]/jax/output/CommonHTML/jax.js 
mosquitoes. At the end of the 24 hours recovery period, Mosquito mortality was recorded and the percentage mortality was calculated [15].

Then Percentage of mosquito mortality was calculated by using the formula:

$$
\text { percentageofmortality }=\frac{\text { Numberofdeadmosquitoes }}{\text { numberofmosquitoestested }} * 100
$$

\section{Determination of LC50 and LC90 of the crude leaf extracts of test plants}

Based on the preliminary screening ethanol and methanol leaf of plant extract were selected and subjected for dose-response bioassays at the concentrations of $50-300 \mathrm{ppm}$. The average mortality after 24 hours was recorded and used to determine LC50 and LC90 values [14].

\section{Phytochemical screening of methanol and ethanol of crude extracts of test plants}

Crude methanol and ethanol extracts of all test plants were subjected to test the presence of major secondary metabolites (alkaloids, flavonoids, terpenoids, tannin, saponin, and phenols following the procedures described by Madike et al., [16] and Bandiola et al., [17].

\section{Data Analysis}

Data from all replications were pooled and mean percent mortalities of larva and adult mosquitoes that are treated with crude leaf extract of the plants were determined by analysis of variance (ANOVA) using SPSS version 20. Fishers Least Significant Difference (LSD) was used to investigate statistical significance between the different test plants against mosquito mortality. The difference between means was considered statistically significant at $P<0.05$. LC50\% and LC90\% and other statistics at 95\% fiducial limit of lower confidence limit and upper confidence limit and Chi-square values were determined using dosage mortality probit regression analysis of SPSS program version 20 to determine their larvicidal and adulticidal efficacies [14].

\section{Results}

\section{Ethnobotanical Plant Species that used to repel Mosquito in the Study Area}

Fifteen local plant species used to repel mosquitoes were reported from the study area and identified (Table 1). From fifteen local plant species, the most frequently used plant was Azadirachta indica A. (75\%), Ocimum lamiifolium Hochst ex. Benth. (65\%), Ocimum americanum L. (70\%), leaf of Moringa olifiera L. (50\%), and seeds of Moringa olifiera L. (50\%) and selected to test the larvicidal and adulticidal effect of these plant extract against $A n$. arabiensis. 
Table 1

Plant species collected from the three kebeles of Dangur district

\begin{tabular}{|c|c|c|c|c|c|}
\hline $\begin{array}{l}\text { Scientific } \\
\text { Name }\end{array}$ & $\begin{array}{l}\text { Vernacular } \\
\text { Name }\end{array}$ & $\begin{array}{l}\text { Family } \\
\text { Name }\end{array}$ & $\begin{array}{l}\text { Plant } \\
\text { type }\end{array}$ & $\begin{array}{l}\text { Part used } \\
\text { and } \\
\text { methods } \\
\text { of } \\
\text { application }\end{array}$ & $\begin{array}{l}\text { Usage } \\
\text { frequency } \\
(\%)\end{array}$ \\
\hline Allium sativum L. & $\begin{array}{l}\text { Nech Shenkurt } \\
\text { (A) }\end{array}$ & Alliaceae & Herbs & $\begin{array}{l}\text { Crushing } \\
\text { the } 3-5 \\
\text { bulb and } \\
\text { applying } \\
\text { the juice to } \\
\text { the body }\end{array}$ & $5 \%$ \\
\hline $\begin{array}{l}\text { Azadirachta } \\
\text { indica } \mathrm{A} \text {. }\end{array}$ & Meem(A)Lemima(G) & Meliaceae & Tree & $\begin{array}{l}10-15 \\
\text { Leaves put } \\
\text { in the } \\
\text { house }\end{array}$ & $90 \%$ \\
\hline Carica papaya L. & Papayaa(A) & Caricacae & Tree & $\begin{array}{l}5 \text { leaves } \\
\text { crushing } \\
\text { and apply } \\
\text { the juice to } \\
\text { the } \\
\text { exposed } \\
\text { parts of } \\
\text { the body. }\end{array}$ & $10 \%$ \\
\hline Citrus sinensis L. & Birtukan(A) & Rutaceae & Tree & $\begin{array}{l}\text { The fruit } \\
\text { peeled and } \\
\text { burning to } \\
\text { generate } \\
\text { smoke }\end{array}$ & $15 \%$ \\
\hline $\begin{array}{l}\text { Crotonmacrostachyus } \\
\text { Hochst. Ex Del. }\end{array}$ & Bissana(A) & Euphorbiaceae & Tree & $\begin{array}{l}\text { Burning } \\
\text { the dried } \\
8-10 \\
\text { leaves to } \\
\text { generate } \\
\text { smoke. }\end{array}$ & $5 \%$ \\
\hline $\begin{array}{l}\text { Cymbopogon citratus } \\
\text { Stapf. }\end{array}$ & Tej sar(A) & Poaceae & Herb & $\begin{array}{l}\text { Burning } 10 \\
\text { of the leaf } \\
\text { plant to } \\
\text { generate } \\
\text { smoke }\end{array}$ & $10 \%$ \\
\hline $\begin{array}{l}\text { Echinops keberich } \\
\text { Mesfn. }\end{array}$ & $\begin{array}{l}\text { Kebericho(A) } \\
\text { Asitana(G) }\end{array}$ & Asteraceae & Herb & $\begin{array}{l}3 \text { Dried } \\
\text { root parts } \\
\text { and } \\
\text { burned to } \\
\text { generate } \\
\text { smoke }\end{array}$ & $25 \%$ \\
\hline $\begin{array}{l}\text { Eucalyptus globulus } \\
\text { L. }\end{array}$ & $\begin{array}{l}\text { Nech bahirzaf } \\
\text { (A }\end{array}$ & Myrtaceae & Tree & $\begin{array}{l}\text { Burning } \\
\text { the whole } \\
\text { plant to } \\
\text { generate } \\
\text { smoke }\end{array}$ & $10 \%$ \\
\hline
\end{tabular}




\begin{tabular}{|c|c|c|c|c|c|}
\hline $\begin{array}{l}\text { Scientific } \\
\text { Name }\end{array}$ & $\begin{array}{l}\text { Vernacular } \\
\text { Name }\end{array}$ & $\begin{array}{l}\text { Family } \\
\text { Name }\end{array}$ & $\begin{array}{l}\text { Plant } \\
\text { type }\end{array}$ & $\begin{array}{l}\text { Part used } \\
\text { and } \\
\text { methods } \\
\text { of } \\
\text { application }\end{array}$ & $\begin{array}{l}\text { Usage } \\
\text { frequency } \\
\text { (\%) }\end{array}$ \\
\hline $\begin{array}{l}\text { Eucalyptus } \\
\text { camaldulensis Dehn. }\end{array}$ & Key beharzaf $(A)$ & Myrtaceae & Tree & $\begin{array}{l}\text { Burning } \\
\text { the whole } \\
\text { plant to } \\
\text { generate } \\
\text { smoke }\end{array}$ & $10 \%$ \\
\hline \multirow{2}{*}{$\begin{array}{l}\text { Moringa olifiera L. } \\
\text { leaf }\end{array}$} & Sheferaw $(A)$ & \multirow[t]{2}{*}{ Moringaceaea } & \multirow[t]{2}{*}{ Tree } & \multirow{2}{*}{$\begin{array}{l}15-20 \\
\text { Leaves put } \\
\text { in the } \\
\text { house }\end{array}$} & \multirow[t]{2}{*}{$50 \%$} \\
\hline & Chehwie(G) & & & & \\
\hline \multirow{2}{*}{$\begin{array}{l}\text { Moringa olifiera L. } \\
\text { seed }\end{array}$} & Sheferaw(A) & \multirow[t]{2}{*}{ Moringaceaea } & \multirow[t]{2}{*}{ Tree } & \multirow{2}{*}{$\begin{array}{l}20-30 \\
\text { Seeds } \\
\text { crushed } \\
\text { and } \\
\text { rubbed on } \\
\text { the skin }\end{array}$} & \multirow[t]{2}{*}{$50 \%$} \\
\hline & Chehwie(G) & & & & \\
\hline $\begin{array}{l}\text { Ocimum lamiifolium } \\
\text { Hochst, ex Benth. }\end{array}$ & Damakasse(A)Akawaya(G) & Lamiaceae & Shrub & $\begin{array}{l}\text { About } 5 \\
\text { leaves of } \\
\text { the juice } \\
\text { applied to } \\
\text { the skin }\end{array}$ & $65 \%$ \\
\hline $\begin{array}{l}\text { Ocimum americanum } \\
\text { L. }\end{array}$ & $\begin{array}{l}\text { Yezenjero } \\
\text { Zekakebie(A)Omasiya(G) }\end{array}$ & Lamiaceae & Shrub & $\begin{array}{l}\text { About } 5 \\
\text { leaves of } \\
\text { the juice } \\
\text { applied to } \\
\text { the skin }\end{array}$ & $70 \%$ \\
\hline $\begin{array}{l}\text { Olea europaea } \\
\text { L. }\end{array}$ & Woira(A) & Oleaceae & Tree & $\begin{array}{l}3 \text { stem } \\
\text { parts of } \\
\text { the plant } \\
\text { burned to } \\
\text { generate } \\
\text { smoke }\end{array}$ & $20 \%$ \\
\hline $\begin{array}{l}\text { Otostegia integrifolia } \\
\text { Benth. }\end{array}$ & Tnjut(A) & Lamiaceae & Shrub & $\begin{array}{l}\text { Dried } 10 \\
\text { leaf and } \\
\text { smoke }\end{array}$ & $25 \%$ \\
\hline Ruta chalepensis L. & Tena Adam (A) & Rutaceae & Herb & $\begin{array}{l}\text { Thermal } \\
\text { expulsion } \\
\text { and direct } \\
\text { burning of } \\
\text { seeds }\end{array}$ & $20 \%$ \\
\hline
\end{tabular}

\section{Larvicidal Activity of Crude Leaf and Seed Extracts of the Test Plants}


The highest mortality was recorded in ethanol leaf extract of $A$. indica (95\%). However, the methanol leaf extract of 0 . lamiifolium recorded the lowest activity with mortality of $63.35 \%$ (Table 2 ).

Table 2

Larvicidal activity of ethanol and methanol crude leaf and seed plant extract of test plants against 4th instar of larvae of An. arabiensis at 300ppm

\begin{tabular}{|lll|}
\hline \% Mean mortality \pm SE & & \\
\hline Plant species & Solvent & Methanol \\
\cline { 2 - 3 } & Ethanol & $65 \pm 1.528^{\mathrm{Ba}}$ \\
\hline Azadirachta indica & $95 \pm 0.577^{\mathrm{Aa}}$ & $63.35 \pm 3.480^{\mathrm{Bab}}$ \\
\hline Ocimum lamiifolium & $90 \pm 0.577^{\mathrm{Aab}}$ & $76.65 \pm 0.667^{\mathrm{Babc}}$ \\
\hline Ocimum Americanum & $88.25 \pm 0.333^{\mathrm{Aabc}}$ & $91.65 \pm 0.882^{\mathrm{Ac}}$ \\
\hline Moringa olifiera leaf & $86.65 \pm 0.667^{\mathrm{Abc}}$ & $90 \pm 0.557^{\mathrm{Ac}}$ \\
\hline Moringa olifiera seed & $83.35 \pm 0.333^{\mathrm{Abc}}$ & $0.00 \pm 0.000^{\mathrm{Ad}}$ \\
\hline Negative Control & $0.00 \pm 0.000^{\mathrm{Ad}}$ & \\
\hline * Each value (\% mean \pm SE) represents mean value of three replicates. & \\
\hline $\begin{array}{l}\text { * Means followed by the same letters within the same row (Upper case) and within the same column (Lower } \\
\text { case) are not significantly different }(\mathrm{p}>0.05)\end{array}$ \\
\hline
\end{tabular}

There was no statistically significant $(p>0.05)$ difference in the larvicidal potential between ethanol and methanol extract of $M$. olifiera leaf and $M$. olifiera seed. However, there was a significant difference $(p<0.05)$ in the larvicidal efficacy between ethanol and methanol leaf extracts of $A$. indica, $O$. lamiifolium, and $O$. americanum.

\section{Determination of LC50 and LC90 of Leaf and Seed Crude Plant Extract}

Ethanol leaf extract of $A$. indica, 0 . lamiifolium, 0 . americanum, and methanol extract of $M$. olifiera leaf and $M$. olifiera seed were subjected (Table 3 ). Ethanol leaf extract of $A$. indica caused the highest larvicidal activities against the 4th instar larvae of An. arabiensis with the lowest LC50 of 40.73 ppm and LC90 of 186.66 ppm. Ethanol crude leaf extract of 0 . americanum relatively showed the highest LC50 and LC90 (LC50 = 92.42 ppm, LC90 $=551$ ppm) 
Table 3

LC50 and LC90 of test plant extract against larvae of An. arabiensis.

\begin{tabular}{|c|c|c|c|c|c|c|c|c|}
\hline Solvent & Plant name & LC 50 & LCL & UCL & LC90 & LCL & UCL & $\begin{array}{l}X^{2} \\
\left(d f^{b}=4\right)\end{array}$ \\
\hline \multirow[t]{3}{*}{ Ethanol } & Azadirachta indica & 40.73 & 10.38 & 65.31 & 186.66 & 131.97 & 378.50 & 0.339 \\
\hline & Ocimum lamiifolium & 40.93 & 5.35 & 69.23 & 230 & 170.5 & 944.18 & 0.744 \\
\hline & $\begin{array}{l}\text { Ocimum } \\
\text { americanum }\end{array}$ & 92.42 & 45 & 129.22 & 551 & 318 & 3092 & 1.419 \\
\hline \multirow[t]{2}{*}{ Methanol } & Moringa olifiera leaf & 45.43 & 11.93 & 72 & 260 & 159 & 558 & 0.390 \\
\hline & Moringa olifiera seed & 62.35 & 19.1 & 94.01 & 388 & 239.75 & 1792.11 & 2.831 \\
\hline
\end{tabular}

*LC50-Lethal concentration that kills $50 \%$ of the exposed larvae, LC90-Lethal concentration that kills $90 \%$ of the exposed larvae, $\mathrm{UCL}=$ Upper confidence limit, $\mathrm{LCL}=$ Lower confidence limit, $\mathrm{X}^{2}$ - chi-square, df- degree of freedom

\section{Adulticidal Activity of Crude Leaf and Seed Extracts of the Test Plants}

The highest mortality was recorded in methanol leaf extract of $A$. indica (75\%) (Table 4). However, the ethanol and methanol leaf extract of $M$. olifiera lowest mortality with $50 \%$ (Table 4). No adult mortality was observed in the negative control during the experiment. 
Table 4

Adulticidal activity of ethanol and methanol crude plant extract of test plants against adult of An. arabiensis at 300ppm

\section{$\%$ Mean mortality \pm SE}

\section{Plant species}

Azadirachta indica

Ocimum lamiifolium

Ocimum americanum

Moringa olifiera leaf

Moringa olifiera seed

Negative Control

\section{Solvent}

Ethanol

$71.65 \pm 0.333^{\mathrm{Aa}}$

$70 \pm 0.577^{\mathrm{Aa}}$

$55 \pm 0.577^{\mathrm{Ab}}$

$50 \pm 0.577^{A b}$

$55 \pm 0.881^{A b}$

$0.00 \pm 0.000^{\mathrm{Ac}}$

* Each value (\% mean \pm SE) represents mean value of three replicates.

* Means followed by the same letters within the same row (Upper case) and within the same column (Lower case) are not significantly different $(p>0.05)$

There was no statistically significant $(p>0.05)$ difference in the adulticidal potential between ethanol and methanol extract of all test plants. However, there was a significant difference $(p<0.05)$ in the adulticidal efficacy between ethanol leaf extracts of $A$. indica and 0 . americanum and

\section{Determination of LC50 and LC90 of Crude Leaf Plant Extracts}

Methanol leaf extract of $A$. indica caused the lowest LC50 of 106.655ppm and LC90 of 1293ppm and Ethanol crude leaf extract of $A$. indica showed the highest LC50 and LC90 (LC50 = 151.033ppm, LC90 = 1059 ppm) (Table 5). 
Table 5

LC50 and LC90 of test plant leaf extracts against adult An. arabiensis

\begin{tabular}{|c|c|c|c|c|c|c|c|c|}
\hline Solvent & Plant name & LC50 & LCL & UCL & LC90 & LCL & UCL & $X^{2}\left(d f^{b}=4\right)$ \\
\hline \multirow[t]{2}{*}{ Ethanol } & $\begin{array}{l}\text { Azadirachta } \\
\text { indica }\end{array}$ & 151.033 & 96.794 & 232.69 & 1059 & 486.47 & 20498.55 & 0.360 \\
\hline & $\begin{array}{l}\text { Ocimum } \\
\text { Lamiifolium }\end{array}$ & 125.48 & 50.472 & 206.825 & 1468.15 & 526.74 & 88685.0 & 0.471 \\
\hline \multirow[t]{2}{*}{ Methanol } & $\begin{array}{l}\text { Azadirachta } \\
\text { indica }\end{array}$ & 106.655 & 30.232 & 168.537 & 1293 & 481.79 & 751031 & 1.099 \\
\hline & $\begin{array}{l}\text { Ocimum } \\
\text { lamiifolium }\end{array}$ & 158.50 & 105.391 & 245.687 & 1054.1 & 491.37 & 17355.7 & 0.045 \\
\hline
\end{tabular}

\section{Phytochemical Screening of Methanol and Ethanol Crude Leaf and Seed Extracts of Test Plants}

Phytochemical screening was conducted for all methanol and ethanol crude plant extract to test the presence of alkaloids, flavonoids, terpenoids, tannin, saponin, and phenols and the results were presented in Table 6.

Table 6: Phytochemical screening of methanol and ethanol crude extracts of test plants

Plant name Solvent Secondary metabolite

\begin{tabular}{|c|c|c|c|c|c|c|c|}
\hline & & \\
\hline & & Alkaloids & Flavonoids & Terpinoids & Tannin & Saponin & Phenols \\
\hline \multirow{2}{*}{$\begin{array}{l}\text { Azadirachta } \\
\text { indica }\end{array}$} & Ethanol & + & + & + & + & + & + \\
\hline & Methanol & + & + & + & + & + & + \\
\hline \multirow{2}{*}{$\begin{array}{l}\text { Ocimum } \\
\text { lamiifolium }\end{array}$} & Ethanol & + & - & + & + & + & + \\
\hline & Methanol & + & - & + & + & + & + \\
\hline \multirow{2}{*}{$\begin{array}{l}\text { Ocimum } \\
\text { americanum }\end{array}$} & Ethanol & - & - & + & - & - & + \\
\hline & Methanol & - & - & + & - & - & + \\
\hline \multirow{2}{*}{$\begin{array}{l}\text { Moringa } \\
\text { olifiera leaf }\end{array}$} & Ethanol & + & + & + & + & + & - \\
\hline & Methanol & + & + & + & + & + & + \\
\hline \multirow{2}{*}{$\begin{array}{l}\text { Moringa } \\
\text { olifiera seed }\end{array}$} & Ethanol & + & + & + & - & - & - \\
\hline & Methanol & + & + & + & - & - & + \\
\hline
\end{tabular}


$+=$ Present, - = absent

\section{Discussions}

A total of fifteen local plant species were identified to be used for mosquito control in Dangur district. The presence of several plant species to be used for mosquito control by the local people is a good indication of the deep-rooted culture of local plants used in the study area. This result is similar to other studies conducted in Ethiopia in two plants $[18,19]$. The current result showed that the local communities had more indigenous knowledge and give emphasis to use the local plants to repel mosquitoes. Out of all local plant species used for mosquito control the most frequently used plants were Azadirachta indica A.(75\%), Ocimium lamiifolium Hochst ex. Benth. (65\%), Ocimium amiricanum L. (70\%), leaf of Moringa olifiera L.(50\%), and seeds of Moringa olifiera L.(50\%). Some of the repellant plants recorded in current study were also reported in other parts of Ethiopia [9, $20,21]$.

All the test plants were found to have potential larvicidal activities against the 4th instar larvae of An. arabiensis at the test concentration. The highest mortality was recorded in ethanol leaf extract of $A$. indica, the methanol leaf extract of $M$. olifiera, the ethanol leaf extract of $O$. lamiifolium, and methanol seed extract $M$. olifiera with mortality of $95 \%, 91.65 \%, 90 \%$, and $90 \%$, respectively. However, the methanol leaf extract of 0 . lamiifolium, $A$. indica, 0 . americanum followed by ethanol seed extract of $M$. olifiera, the leaf extract of $M$. olifiera, and leaf extract of 0 . americanum recorded the lowest activity with mortality of $63.35 \%, 65 \%, 76.65 \%, 83.35 \%, 86.65 \%$, and $88.25 \%$, respectively. The toxicity difference among test plants and extraction solvent suggested that different plants have different phytochemicals which can be extracted by different solvents.

High larval mortality was caused by ethanol leaf extract of $A$. indica with mortality $95 \%$. This finding is similar to the report of Okumu et al. [22]. where hexane leaf extract of $A$. indica was found to cause $100 \%$ mortality against larvae of $A n$. gambiae at 1000 ppm although the concentrations are different. This could be due to the presence of excess bioactive secondary metabolites.

However, this finding disagrees with finding of Vilayatakar et al. [23] that reported the aqueous extract of $M$. oleifera leaves against larvae of Anopheles which has shown 60\% mortality at 500ppm. Similarly, acetone extract of $O$. lamiifolium oil was found to have high larvicidal activity against An. arabiensis [24]. Various factors might be responsible for the larvicidal activity, but the difference in larvicidal activities in the current finding could be due to locality of the plants, and different solvents.

Methanol leaf extract of $A$. indica cause adult mortality with mortality $75 \%$ which could be due to the presence of bioactive secondary metabolites. This finding is in line with the earlier finding of Kamaraj et al. [25]. who reported adulticidal efficacy of methanol against $C x$. gelidus Theobald.

Ethanol leaf extract of 0 . lamiifolium and 0 . americanum were found to have $71.65 \%$ and $55 \%$ mortality respectively at 300 ppm against adults of An. arabiensis after 24 hours' exposure. This result is lower compared to the finding of Messebo et al. [26]. where ethanol leaf extract of 0 . lamiifolium showed $90 \%$ mortality against the adult $A n$. arabiensis after 1 hour exposure $0.25(\mathrm{v} / \mathrm{v})$ in other part of Ethiopia. The difference in adulticidal activities with the current finding could be due to species of plants, extraction solvent, and locality of the plants. 


\section{Conclusions}

Ethnobotanical plants are widely used in Dangur district, northwestern Ethiopia. The Azadirachta indica, Ocimum lamiifolium, Ocimum americanum, Moringa olifiera leaf, and Moringa olifiera are plant species frequently used for mosquito prevention in Northwest Ethiopia. They have effective larvicidal potential against 4th instar larvae of Anopheles arabiensis. Ethanol leaf extract of $A$. indica has higher larvicidal potential and promising for further botanical insecticide developments. Ethanol and methanol extract of $A$. indica and $O$. lamiifolium have potential adulticidal activity with mortality $>60 \%$ mortality against adult of $A n$. arabiensis. The phytochemical analysis of leaf extract of $A$. indica has secondary metabolites such as alkaloid, flavonoid, terpenoid, tannin, saponin, and phenols which have potential insecticidal activities. Finally, we recommend further study to identify the active ingredient of ethanol and methanol extracts of $A$. indica and their mode of action in the study area and other parts of Ethiopia.

\section{Declarations}

\section{Ethical approval and consent to participant:}

not applicable

\section{Consent for publication:}

not applicable

\section{Availability of data and materials:}

The datasets used and/or analyzed during the current study are available from the corresponding author on reasonable request.

\section{Competing interests:}

The authors declare that they have no competing interests"

\section{Funding:}

The funding for this work was obtained from Assosa University.

\section{Authors' contributions}

AA conducted the laboratory work and interpreted the data and wrote the first draft of the manuscript. DE and AA designed the field collection protocols and oversaw the collection. DE provided a critical revision of the manuscript. All authors have read and approve the content of the submitted manuscript.

\section{Acknowledgements:}

We thank Assosa University for funding. We are very much grateful for lab technicians of Tropical and Infectious Diseases Research Center, Assosa University for technical assistant. We acknowledge community of Dangur district, particularly key informant of the study villages. 
All authors are from Assosa University, Assosa, Ethiopia

\section{References}

1. Tulu AN. Malaria. In Kloos H, Zein ZA (eds). The Ecology of Health and Disease in Ethiopia. Boulder: Westview Press. 1993.

2. Gebremariam N. Malaria. In Zein ZA. Kloos H (eds). The Ecology of Health and Disease in Ethiopia. Ministry of Health: Addis Ababa; 1988.

3. Balkew M, Mumba P, Yohannes G, Abiy E, Getachew D, Yared S, Worku A, Gebresilassie A, Tadesse FG, Gadisa E, Esayas E, Ashine T, Ejeta D, Dugassa Sisay, Yohannes M, Lemma W, Yewhalaw D, Chibsa S, Teka H, Murphy M, Yoshimizu M, Dengela D, Zohdy S, Irish S. An update on the distribution, bionomics, and insecticide susceptibility of Anopheles stephensi in Ethiopia, 2018-2020. Malar J. 2021;20:263.

4. Yewhalaw D, Wassie F, Steurbaut W, Sponaghe P, Van Bortel W, Denis L, Tessema DA, Getachew Y, Coosemans M, Duchateau L, Speybroeck N. Multiple insecticide resistance: an impediment to insecticidebased malaria vector control program. PLoSEONE. 2011; (6):e16066. doi:10.1371/journal.pone.0016066.

5. Balkew M, Getachew A, Chibsa S, Olana D, Reithinger R, Brogdon W. Insecticide resistance a challenge to malaria vector control in Ethiopia. Malar J. 2012;11 suppl 1:139.

6. Hebbalkar YE, Temu EA, Amin E, Rayah E, Munga S, Kweka EJ. Chemical cues for malaria vectors oviposition site selection: challenges and opportunities. J Insects. 2013;1:9.

7. Ejeta D. Ethno-botanical Survey of Plants Used for Prevention Against Mosquito Bites and Control of Malaria in Assosa District, Western Ethiopia. Int J Ethnobiol Ethnomed. 2019;4:12.

8. Kweka EJ, Lima TC, Marciale CM, de Sousa DP. Larvicidal efficacy of monoterpenes against the larvae of Anopheles gambiae. Asian Pac J Trop Biomed. 2016;6:290-4.

9. Karunamoorthi K, llango K, Endale A. Ethnobotanical survey of knowledge and usage custom of traditional insect/mosquito repellent plants among the Ethiopian Oromo ethnic group. J Ethnopharmacol. 2009;125:224-9.

10. Karunamoorthi K, llango K. Larvicidal activity of Cymbopogon citratus (DC) Stapf. and Croton macrostachyus Del. against Anopheles arabiensis Patton, a potent malaria vector. Eur Rev Med Pharmacol Sci. 2010;14:57-62.

11. Martin GJ. Ethnobotany: A method Manual. London: Chapman and Hall; 1995.

12. Sebsebe D. Myrsinaceae. In: Hedberg I, Edwards S, Nemomissa S, editors. Flora of Ethiopia and Eritrea. Addis Ababa University. 4: Addis Ababa, Ethiopia, and Uppsala, Sweden.; 2003. pp. 64-9.

13. Tomass Z, Hadis M, Taye A, Mekonnen Y. Larvicidal effects of Jatropha curcas L. Against Anopheles arabiensis (Diptera: Culicidae). Momona. 2011;3:52-64.

14. WHO. Guidelines for laboratory and field testing of mosquito larvicides. World Health Organization; 2005.

15. WHO. Guidelines for Testing Mosquitoes Adulticides for Indoor Residual Spraying and Treatment of Mosquito Nets. Geneva: World Health Organization; 2006.

16. Madike LN, Takaidza S, Pillay M. Preliminary phytochemical screening of crude extracts from the leaves, Loading [MathJax]/jax/output/CommonHTML/jax.js Int J Pharmacogn Phytochem Res. 2017;9:1300-8. 
17. Bandiola TMB. Extraction and qualitative phytochemical screening of medicinal plants: A Brief Summary. Int J Pharm. 2018;8:137-43.

18. Bekele D, Asfaw Z, Petros B, Tekie H. Ethnobotanical study of plants used for protection against insect bite and the treatment of livestock health problems in rural areas of Akaki District, Eastern Shewa, Ethiopia. TC. J. Herb. Med. 2012; 1 suppl 2: 12-24.

19. Kaliyaperumal K, Mulelam A, Wassie F. Assessment of knowledge and usage custom of traditional insect/mosquito repellent plants in Addis Zemen Town, South Gonder, North Western Ethiopia. J Ethnopharmacol. 2008;121:49-53.

20. Karunamoorthi K, Hailu T. Insect repellent plants traditional usage practices in the Ethiopian malaria epidemic-prone setting: An ethnobotanical survey. J Ethnobiol Ethnomedicine. 2014;10:22.

21. Baana K, Angwech H, Malinga GM. Ethnobotanical survey of plants used as repellents against houseflies, Musca domestica L. (Diptera: Muscidae) in Budondo Subcounty, Jinja District, Uganda. J Ethnobiol Ethnomed. 2018;14:1-8.

22. Okumu FO, Knols BGJ, Fillinger U. Larvicidal effects of a neem (Azadirachta indica) oil formulation on the malaria vector Anopheles gambiae. Malar J. 2007;6:63.

23. Vilayatakar MB, Thakare VG. Study on larvicidal efficacy of Moringa oleifera against the vector Anopheles Mosquitoes. Bio. Disc. 2018; 9 suppl 3: 365-370.

24. Fekadu M, Mekuria T, Tesfaye B, Meshesha B, Teshome G. Evaluation on larvicidal effects of essential oils of some local plants against Anopheles arabiensis Patton and Aedes aegypti Linnaeus (Diptera, Culicidae) in Ethiopia. Afr J Biotechnol. 2009;8(17):4183-8.

25. Kamaraj C, Rahuman AA, Mahapatra A, Bagavan A, Elango G. Insecticidal and larvicidal activities of medicinal plant extract against mosquitoes. Parasitol Resolution. 2010;107:1337-49.

26. Massebo F, Mekuria T, Balkew M, Gebre-Michael T. Bioactivity of essential oils of local plants against adult Anopheles arabiensis (Diptera: Culicidae) in Ethiopia. Advances in Bioscience Biotechnology. 2013;8:805-9.

\section{Figures}




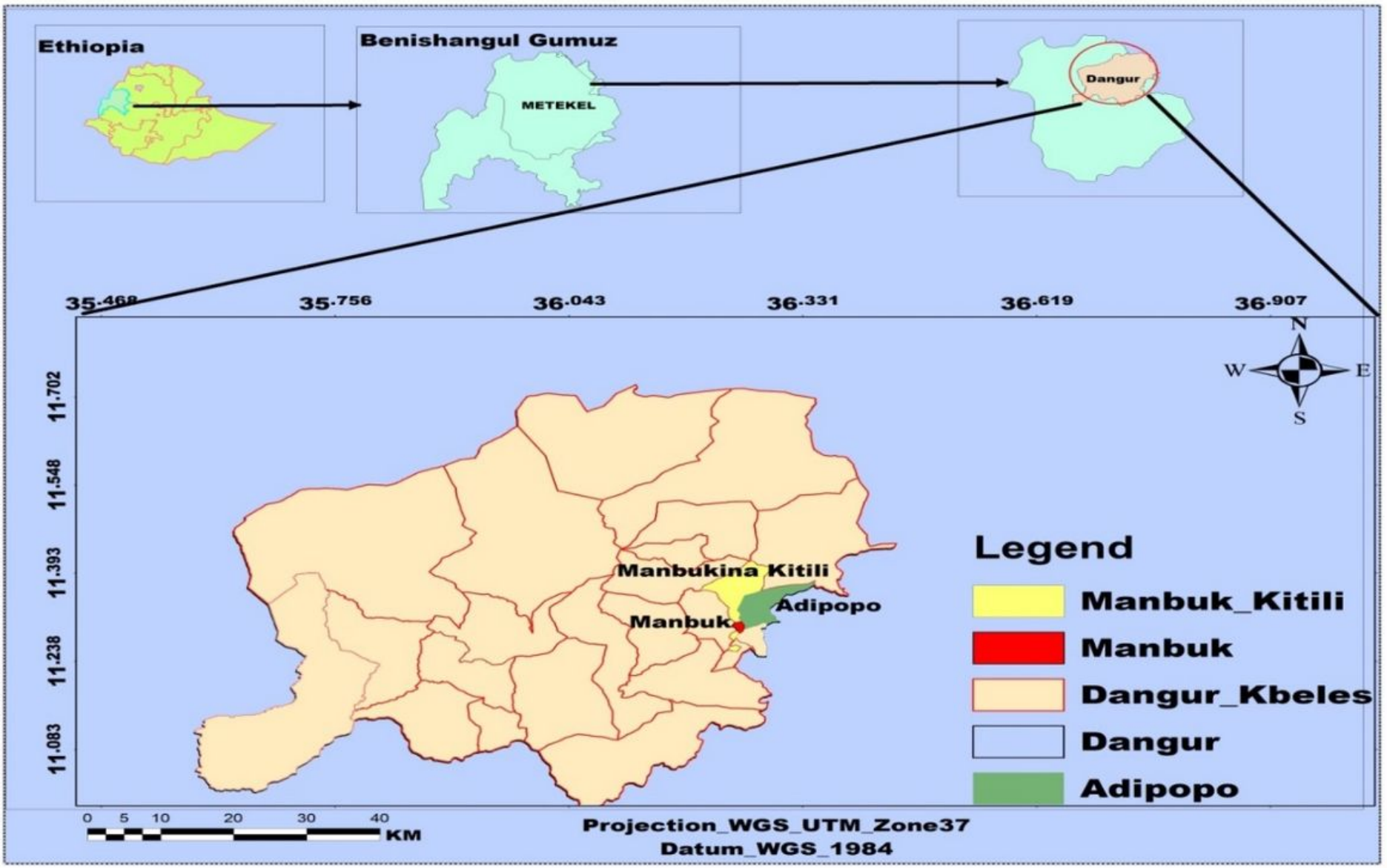

Figure 1

Map of the study area 